\title{
Low levels of pancreatic elastase 1 in stools of preterm infants
}

\author{
F Campeotto, N Kapel, N Kalach, H Razafimahefa, F Castela, L Barbot, P Soulaines, \\ M Dehan, J G Gobert, C Dupont
}

The amount of faecal pancreatic enzyme elastase 1 was significantly lower in 42 preterm newborns than in 12 full term babies at day 2 (89 (3-539) v $354(52-600) \mathrm{\mu g} / \mathrm{g}$, $p<0.0007)$ and day 5 (164 (3-600) v 600 (158-600) $\mu \mathrm{g} / \mathrm{g}, \mathrm{p}<0.05)$ and correlated positively with total nutrient intake during the first week of life in preterm infants. This should probably be taken into account during early feeding.

$\mathrm{P}$ ancreatic elastase 1 (El) is considered to be a highly sensitive and specific marker for exocrine pancreatic function, allowing the diagnosis of pancreatic insufficiency at all ages. ${ }^{1}$ After two weeks of life, whatever the gestational age, $96.8 \%$ of infants without pancreatic disorders exhibit faecal El levels comparable to those of adults. ${ }^{2}$ A preliminary study suggested decreased faecal El levels in infants below 2 weeks of age, ${ }^{3}$ and this prospective study measured faecal El in preterm and full term newborn infants during the first week of life.

\section{METHODS AND RESULTS}

A bicentric prospective study enrolled 42 preterm infants ( 18 girls and 24 boys) born at 28 weeks gestation (median, range 25-35 weeks) and weighing $1140 \mathrm{~g}$ (range 640-1890), including 13 extreme premature infants ( $<28$ weeks gestation). Controls were 12 full term infants (eight girls and four boys) born at term (38-4l weeks) and weighing $3455 \mathrm{~g}$ (range 2840-4160).

For each child, one to three stool samples (about $5 \mathrm{~g}$ ) were obtained during the first two weeks of life and stored at $-20^{\circ} \mathrm{C}$ before analysis. The first sample was obtained between days 0 and 7 (median 2), the second between days 3 and 9 (median 5), and the third between days 7 and 11 (median 9). Owing to monitoring difficulties, two stool samples were collected for 29 of the 42 premature infants and three for the remaining 12 . Three stool samples were not collected for any of the term infants, as they were discharged at 5 days of age.

Pancreatic El levels were determined using a "sandwich" type enzyme immunoassay (Schebo-Biotech, Guiessen, Germany), using two monoclonal antibodies binding to two distinct epitopes specific to human pancreatic El. Results were expressed as $\mu \mathrm{g} / \mathrm{g}$ of stool; $200 \mu \mathrm{g} / \mathrm{g}$ was the lower normal limit. ${ }^{1}$ All quantitative results are given as median (range).

Statistical comparisons were performed using the nonparametric Mann-Whitney U test. Single regression analysis was used to calculate correlation coefficients for parametric data.

In all newborns, faecal El levels increased significantly $(\mathrm{p}<0.0001)$ from the first to the third sample: 113 (3-600), $242(3-600)$, and 459 (559-600) $\mathrm{\mu g} / \mathrm{g}$ respectively. El levels were significantly lower in preterm infants than in full term

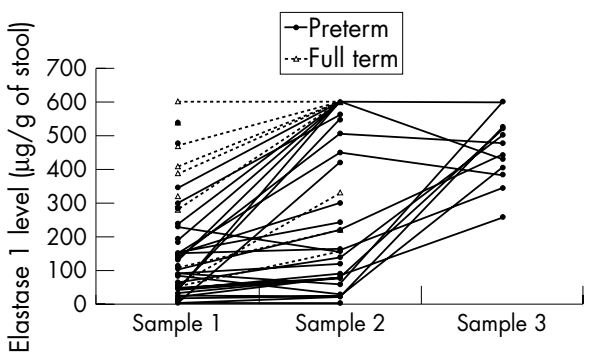

Figure 1 Pancreatic elastase (E1) levels in the two groups of newborn infants. Samples 1, 2, and 3 were collected on median day 2 , median day 5 , and median day 9 respectively. Reference concentrations for pancreatic $\mathrm{El}$ in adult stools are: normal, $\geqslant 200$ $\mathrm{\mu g} / \mathrm{g}$; moderate to light exocrine pancreatic insufficiency, 100 to $<200 \mu \mathrm{g} / \mathrm{g}$; severe pancreatic insufficiency, $\leqslant 100 \mu \mathrm{g} / \mathrm{g}$.

infants at day $2(89(3-539) v 354(52-600) \mu \mathrm{g} / \mathrm{g}, \mathrm{p}<0.0007)$ and day $5(164(3-600) v 600(158-600) \mu g / g, p<0.05)$ (fig l). No difference was found between extremely premature (74 $(3-228) \mu \mathrm{g} / \mathrm{g}$ ) and premature infants (102 (3-539) $\mu \mathrm{g} / \mathrm{g}$ ) $(\mathrm{p}=0.58)$, within the first week of life. All preterm infants displayed normal El levels from the second week onwards.

Considering all infants, a positive correlation was observed between El levels and gestational age in both first week samples: $r=0.5, \mathrm{p}=0.0001$ and $r=0.3, \mathrm{p}=0.03$. A positive correlation was also observed between El levels in the first sample and birth weight: $r=0.5, \mathrm{p}=0.0001$.

In preterms, a positive correlation was observed between El levels in the first sample and total energy $(r=0.47, \mathrm{p}=0.002)$, lipid $(r=0.43, \mathrm{p}=0.004)$, protein $(r=0.45, \mathrm{p}=0.002)$, and carbohydrate $(r=0.47, \mathrm{p}=0.001)$ intake (fig 2$)$.

No correlation was found between faecal El and any of the other clinical parameters of the studied population: sex, maternal treatment with steroids, maternal blood hypertension, acute fetal distress, infection, respiratory distress, intrauterine growth retardation, necrotising enterocolitis, treatment, the day of stool sampling (table 1).

\section{DISCUSSION}

Preterm infants have low levels of faecal El during the first week of life, whereas full term infants do not, suggesting exocrine pancreatic immaturity in the former. The beneficial effect of early enteral feeding on pancreatic exocrine function is supported by the correlation between faecal El increase and nutrient intake.

Considerable variations in faecal El between stool samples and from day to day have been described by Hamwi et al. ${ }^{4}$ The first sample was obtained close to birth, according to the availability of stools during this period of intensive care. This collection may have involved either stool or meconium, which is known to contain low El levels. ${ }^{25}$

More than half $(52 \%)$ of preterm infants still had low pancreatic El $(<200 \mu \mathrm{g} / \mathrm{g}$ of stool $)$ at the end of the first week, 

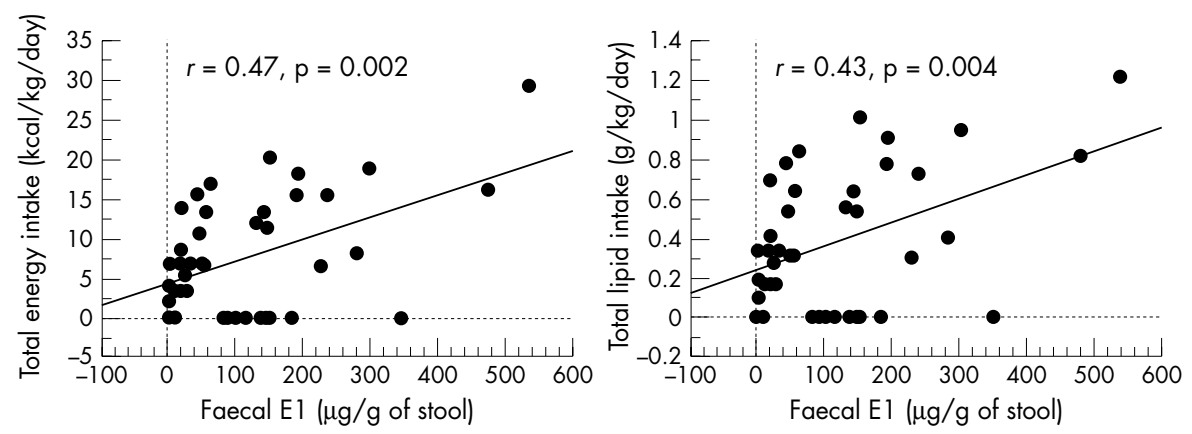

Figure 2 Correlation between faecal elastase 1 (E1) level and nutritional intake in preterm infants in the first sample.
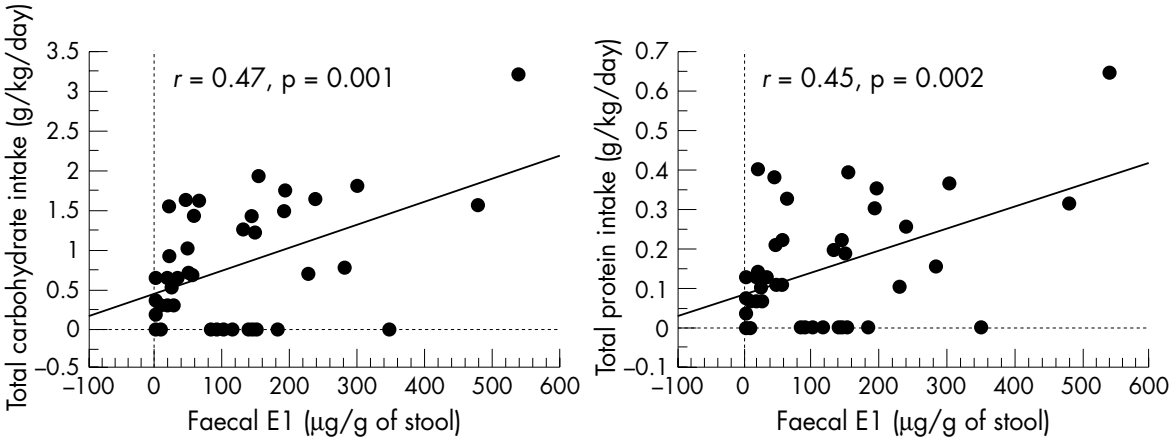

\begin{tabular}{ll}
\hline Table 1 & \multicolumn{1}{c|}{ Clinical features of the 42 preterm infants } \\
\hline & Preterm infants \\
\hline Sex (F:M) & $18: 24$ \\
Gestational age (weeks) & $28(25-35)^{*}$ \\
Birth weight (g) & $1140(640-1890)^{*}$ \\
Maternal steroids & $33(78 \%)$ \\
Maternal hypertension & $11(26 \%)$ \\
Acute fetal distress & $12(28 \%)$ \\
Infection & $8(19 \%)$ \\
Respiratory distress & $39(93 \%)$ \\
Intrauterine growth retardation & $7(17 \%)$ \\
Necrotising enterocolitis & $1(2.4 \%)$ \\
Steroids & $17(40 \%)$ \\
Sedation & $24(57 \%)$ \\
Inotropes & $5(12 \%)$ \\
Volume expansion & $9(21 \%)$ \\
Insulin & $2(5 \%)$ \\
Feeding & $29(70 \%)$ \\
\hline *Values are median (range). & \\
\hline
\end{tabular}

normalise within the first days, more rapidly with enteral nutrition. This should be taken into account during early feeding of preterm infants.

\section{Authors' affiliations}

F Campeotto, N Kalach, F Castela, P Soulaines, C Dupont, Service de Néonatologie, Hôpital Cochin-Saint Vincent de Paul, 82 Avenue Denfert Rochereau, 75674 Paris Cedex 14, France and Université René Descartes, Paris V, France

N Kapel, L Barbot, J G Gobert, Service de Coprologie Fonctionnelle, Groupe Hospitalier Pitié-Salpetrière, 47 Boulevard de l'Hôpital, 75651 Paris Cedex 13, France

H Razafimahefa, M Dehan, Service de Réanimation Néonatale,

Hôpital Antoine Béclère, 157 rue de la Porte-de-Trivaux, 92141 Clamart, France

Correspondence to: Dr Campeotto, Service de Néonatologie, Hôpital Saint Vincent de Paul, 82 Avenue Denfert Rochereau, 75674 Paris cedex 14, France; florence.campeotto@noos.fr

Accepted 11 December 2001

independent of gestational age. Maturation occurs in preterm infants as well as in full term babies after the first week of life, as described by Terbrack $e t a l^{5}$ and Von Seebach and Henker': after one week of life, $97.4 \%$ of term infants (but only $85 \%$ of preterm babies) had reached adult levels of El of $>200 \mathrm{\mu g} / \mathrm{g}$ faeces. After the first week of life, El concentrations remained within the normal adult range. The levels observed during the first week of life remained above values currently observed in cystic fibrosis $(<50 \mu \mathrm{g} / \mathrm{g}$ of stool $){ }^{6}$

The positive correlation between energy and nutrient intakes during the first week of life in preterm infants supports "minimal enteral feeding" as a strategy for accelerating the maturation of gastrointestinal function. ${ }^{7}$ Digestion of nutrients in preterm infants may not be optimal in the first week of life, despite increased needs. Therefore, the trend to sustain "early aggressive enteral feeding" ${ }^{8}$ has probably to be dealt with taking into account pancreatic immaturity: an adaptation of nutrients during the first week seems desirable.

\section{Conclusion}

A pancreatic maturation deficit exists in the first week of life in preterm infants, depending on gestational age. El levels

\section{REFERENCES}

1 Soldan W, Henker J, Sprossig C. Sensitivity and specificity of quantitative determination of pancreatic elastase 1 in feces of children. $J$ Pediatr Gastroenterol Nutr 1997;24:53-5.

2 Von Seebach K, Henker J. Pancreatic Elastase 1 in feces of preterm and term born infants up to 12 months without insuffisiancy of exocrine pancreatic function [abstract]. 21 st European Cystic Fibrosis Conference, Davos (Switzerland), June 1-6, 1997.

3 Campeotto F, Kapel N, Kalach N, et al. Evaluation de la fonction pancréatique exocrine du nouveau-né à terme et du prématuré au cours de la première semaine de vie par le dosage de l'élastase 1 fécale. Arch de la premiere semaine
Pediatr 2001;8:445-6.

4 Hamwi A, Veitl M, Maenner G, et al. Pancreatic elastase 1 in stool: variations within one stool passage and individual changes from day to day. Wien Klin Wochenschr 2000;1 12:32-5.

5 Terbrack HG, Gurtler KH, Klor HU, et al. Human pancreatic elastase 1 concentrations in faeces of healthy children and children with cystic fibrosis. Gut 1995;37:(suppl 2):A253.

6 Walkowiak J. Faecal elastase-1: clinical value in the assessment of exocrine pancreatic function in children. Eur J Pediatr 2000;159:86970.

7 Burrin DG, Stoll B, Jiang R, et al. Minimal enteral nutrient requirements for intestinal growth in neonatal piglets: how much is enough? Am J Clin Nutr 2000;71:1603-10.

8 Thureen PJ. Early aggressive nutrition in the neonate. Pediatrics in Review 1999;20:e45-55. 